\title{
Geological setting and sedimentary characteristics of the coversands distributed in the western part of the Blonie glaciolacustrine basin (Central Poland) - preliminary results
}

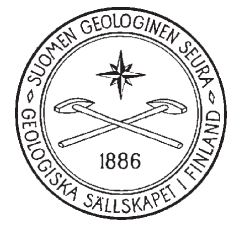

\author{
EDYTA KALIŃSKA \\ University of Tartu, Department of Geology, Institute of Ecology and Earth Sciences, \\ Ravila 14 A, EE-50411 Tartu, Estonia
}

\begin{abstract}
The coversands distributed in the Blonie glaciolacustrine basin, west of Warsaw (Central Poland) were investigated. Textural features including grain size, rounding and frosting of quartz grains and mineralogical-petrographic composition in the sandy fractions (0.50.8 and $0.8-1.0 \mathrm{~mm}$ ) were examined and the types, dynamics, regime and variation in processes during the formation of the coversands were determined. The sands are characterized by the prevalence of quartz and lack of micaceous minerals. Moreover, the relatively high content of partially rounded, matt (EM/RM) and well-rounded (RM) quartz grains, typical of aeolian sedimentary conditions, was certified. Hence, the results show a high aeolization degree of the investigated sediments, thus correlating them with aeolian deposition in dry, periglacial conditions after drying up of the Warsaw icedammed lake.
\end{abstract}

Keywords (GeoRef Thesaurus, AGI): eolian features, cover sands, sand, quartz, grain size, roundness, mineral composition, Blonie, Poland

Corresponding author email: edyta.kalinska@ut.ee

Editorial handling: Pertti Sarala

\section{Study area}

The Blonie glaciolacustrine basin, known also as the eastern part of the Lowicz-Blonie Plain (Kondracki, 2000), is located in Central Poland (Fig. 1B), between Warsaw and Sochaczew (Fig. 1A) in the central part of the European Sand Belt (Zeeberg,
1998; Fig. 1C). The total length of the Blonie basin reaches about $60 \mathrm{~km}$, while the width varies between 20 and $30 \mathrm{~km}$. The basin is surrounded by the higher ground of the Rawa Till Plateau in the south and the lowlying area of the Warsaw Basin in 


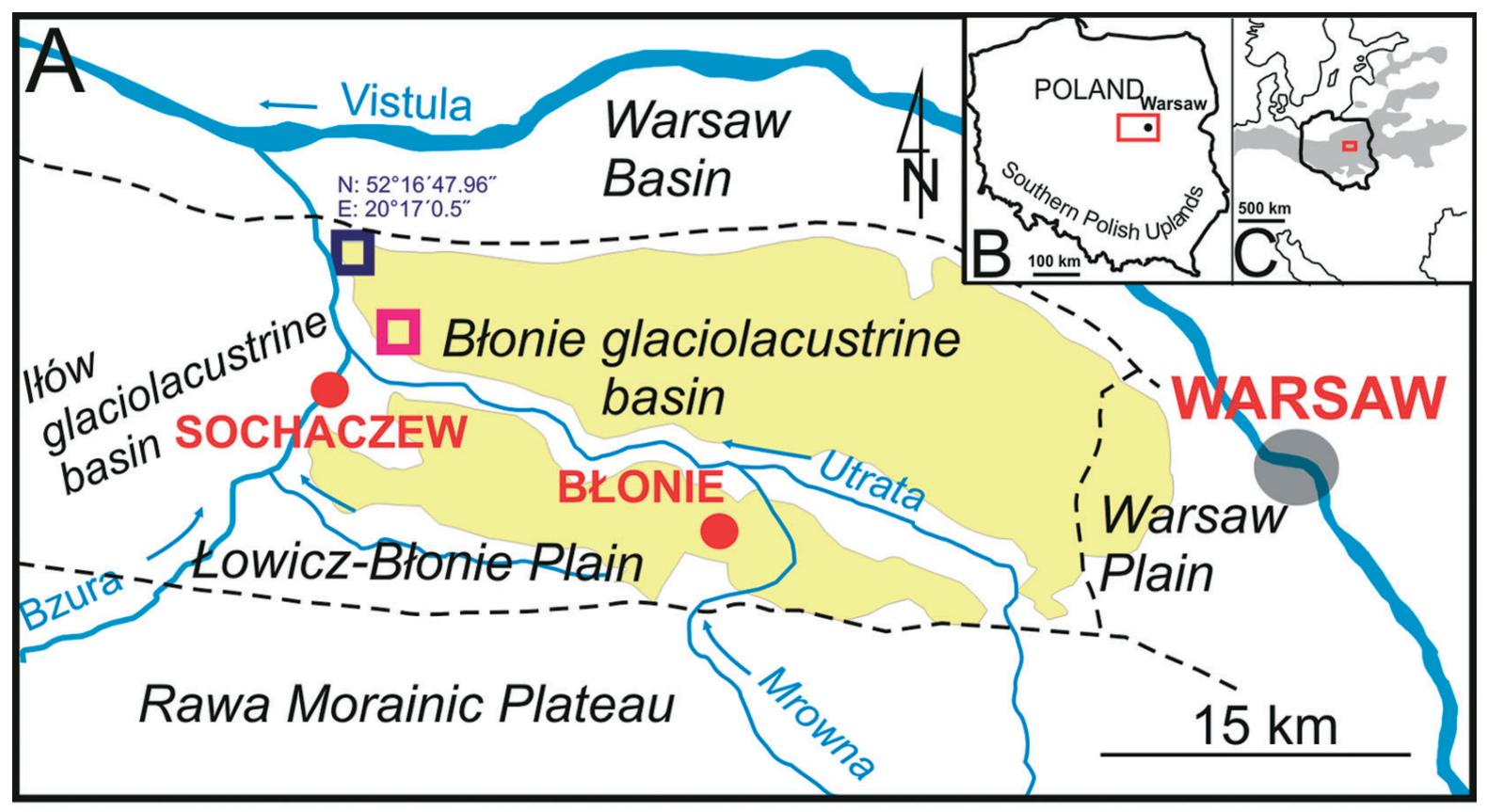

Key

distribution of covesand deposits on Błonie glaciolacustrine basin

(according to Karaszewski, 1972)

ㅁ Plecewice investigated area

C Chodaków investigated area (according to Kalińska, 2008)

Fig. 1. Location of the investigated area and distribution of coversands in the Blonie glaciolacustrine basin (A). Position of the Blonie coversands on the European Sand Belt (grey tint) (Zeeberg, 1998) (B). Location of the Blonie coversands in Poland (C).

the north. It continues as the Ilow glaciolacustrine basin (or the western part of the Lowicz-Blonie Plain according to Kondracki, 2000) to the west, and as the Warsaw Plain to the east. The Blonie and Ilow units are divided by the Bzura River valley (Fig. 1A). The Blonie glaciolacustrine plain is a flat area lying between 82.5 and $100 \mathrm{~m}$ a.s.l. It is built of glaciolacustrine deposits, mostly of varved clays (Halicki, 1933; Merta, 1978). Glaciolacustrine clays accumulated during the Warsaw ice-dammed lake stage, which existed at least during two glacial episodes in the Warsaw Basin: the Warthanian (Saalian) and Vistulian (Weichselian) Glaciations (Marks, 2010). Coversands lie on both glaciolacustrine (Fig. 2) and till deposits forming the highest points (86$90 \mathrm{~m}$ a.s.l.) in the eastern part of the Blonie basin.
The total thickness of coversand deposits varies between 1.5 and $2.0 \mathrm{~m}$ (Fig. 2) and they are more shapeless than dune-like landforms.

So far, the coversands have been insufficiently studied. Karaszewski (1972) showed their distribution and correlated them with the youngest loess level in the Southern Polish Uplands (Fig. 1B). The occurrence of coversands was also investigated during the geological mapping of Blonie Sheet (Szumanski \& Kwapisz, 2006). Some textural features of coversands in the Chodakow area (Fig. 1A) were analyzed in detail by Kalinska (2008a). The aim of this study is to determine the types, dynamics, regime and variation in the processes which have contributed to the formation of the coversands and to establish the origin of these deposits. 


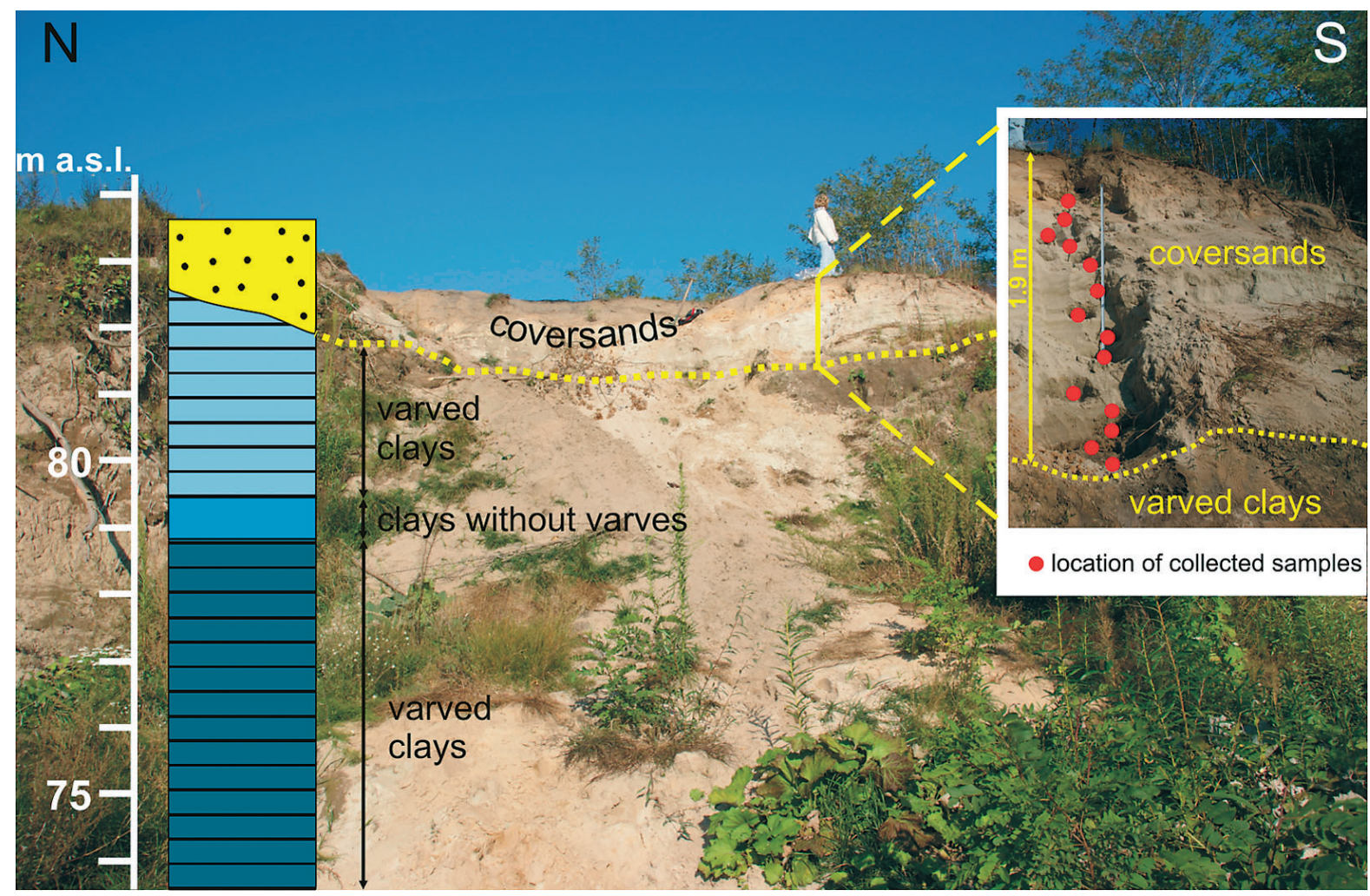

Fig. 2. Geological setting of coversands at the site in Plecewice.

\section{Methods}

Fieldwork including excavation and sampling was conducted in the section in the Plecewice area near the Bzura River (Fig. 1A), in the most north-western part of the Blonie glaciolacustrine basin. Grain size analysis of the samples (41 altogether) was performed by sieving, using the sieve sizes of 2.0, 1.0, $0.8,0.5,0.315,0.25,0.2,0.125,0.1,0.063$ and $0.05 \mathrm{~mm}$. Measuring indexes (mean, standard deviation and skewness), their relationship and graphic representation followed Folk \& Ward (1957). Two graphs were used for detailed description of sediments: the cumulative curves (Fig. $3)$ in the probability scale with the phi $(\phi)$ value on the $\mathrm{x}$-axis and the $\mathrm{t}$ value (cumulative percentage divided by 100 shown in the arithmetic scale), and the frequency curves (Fig. 4) with the phi $(\phi)$ value on the $\mathrm{x}$-axis and the frequency value. After granulometric analysis two groups of grains were selected for further textural analysis: $0.5-0.8 \mathrm{~mm}$

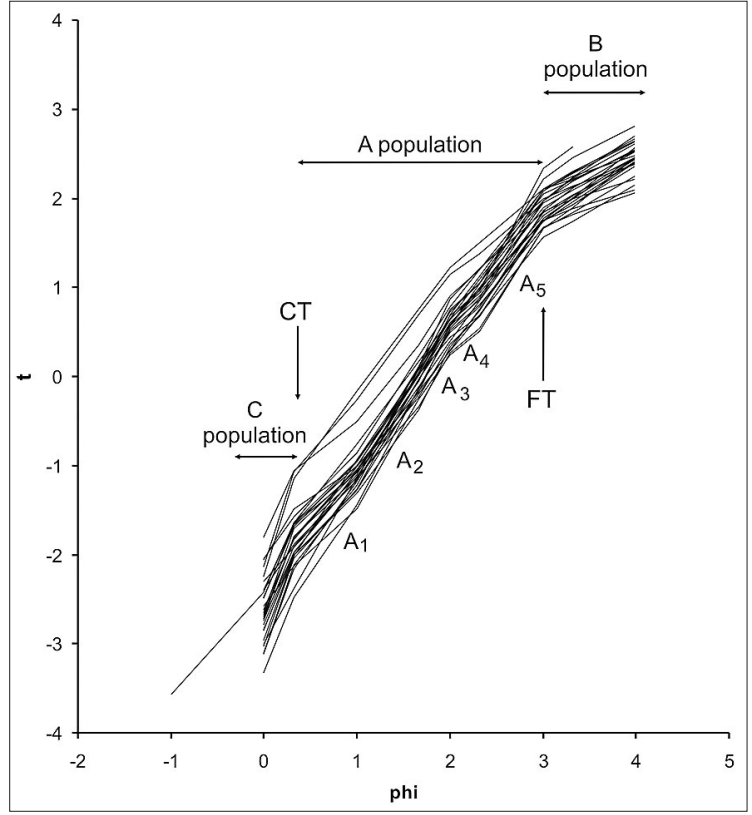

Fig. 3. The cumulative curves of the investgated profile: population A - transportation by saltation; population B - transportation by suspension; population C - transportation by traction; CT - point, which refers to change from the traction transportation to saltation; FT - point, which refers to change from the saltation transportation to suspension. 


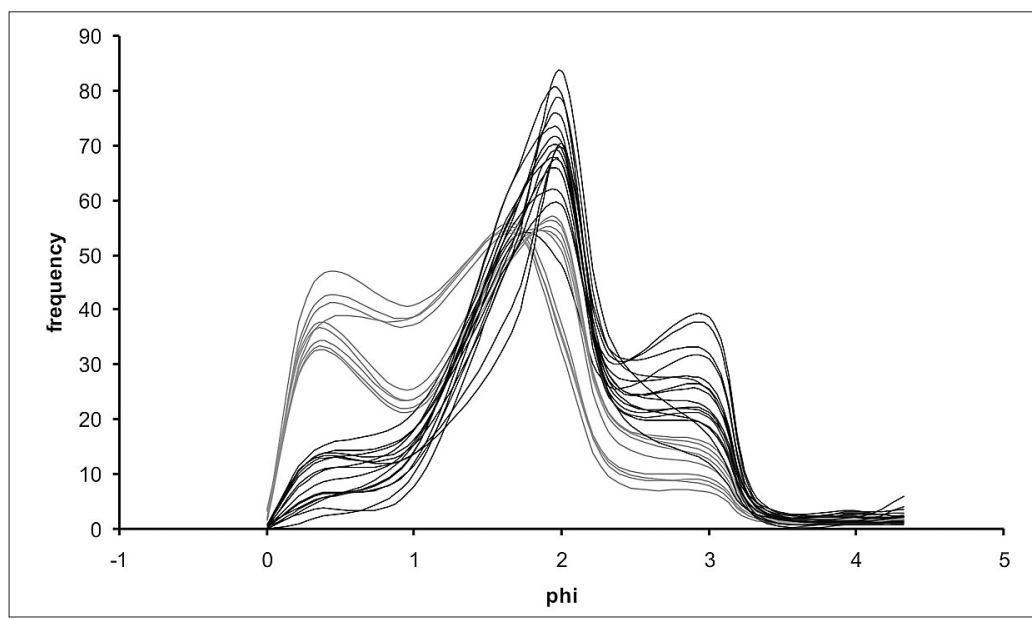

Fig. 4. The frequency curves of the investigated deposits: curves in grey represent the coarsest sand (depths 1.0 and $1.3 \mathrm{~m}$ ).
$(0.8 \mathrm{~mm}$ excluded $)$ and $0.8-1.0 \mathrm{~mm}(0.8 \mathrm{~mm}$ included). To determine the rounding and frosting of the surfaces of quartz grains under the binocular microscope with $25 \times$ magnification, 120-150 grains were randomly selected from both groups. The sand fraction is considered to be most suitable for rounding and frosting studies, because grains become less rounded as the grain size decreases (Caroll, 1939). The effects of wind and water are also best visible in grains of $c a .0 .7 \mathrm{~mm}$ in diameter (Cailleux, 1952; Kotilainen, 2004). Following the method of Cailleux (1942) with modifications from Mycielska-Dowgiallo \& Woronko (1998), six groups of quartz grains were distinguished: nonabraded grains (NU), well-rounded shiny "beachlike” grains (EL), partially rounded shiny grains (EM/EL), well-rounded matt (frosted) grains (RM), partially rounded matt grains (EM/RM) and cracked grains (C). The mineralogical-petrographic composition was determined from the $0.5-0.8 \mathrm{~mm}$ fraction for 220-250 grains. Four groups were distinguished: quartz, feldspars, particles of crystalline rocks and micaceous minerals.

\section{Sedimentary characteristics of the coversands}

\subsection{Grain size}

The medium diameter $(\mathrm{Mz})$ varies within 1.06-1.9 $\phi$ (Fig. 5A \& Table 1). The finest deposits occur in the lowest parts of the profiles (e.g. 1.6-1.9 m) near the contact with glaciolacustrine clays (varved deposits). Two depths, 1.0 and $1.3 \mathrm{~m}$, are characterized by the presence of coarse-grained sands (1.31 and $1.06 \phi$, respectively). Sorting is moderate, whereas the standard deviation $\left(\sigma_{1}\right)$ varies within $0.59-$ 0.84 . The best sorting is noted in the uppermost (between 0.4 and $0.8 \mathrm{~m}$ ) and the lowermost (1.9 $\mathrm{m})$ parts of the profile. Deposits are positively skewed in almost all cases. The relationship between the mean diameter of grains and standard deviation (Fig. 6A) represents the so-called third system of the points location according to Mycielska-Dowgiallo (2007), which is characterized by an approximate value of sorting degree $\left(\sigma_{1}\right)$ and a differentiated mean $(\mathrm{Mz})$ (Fig. 6). The coarsest portion of the profile represents a separate group of points in the lower part of the diagram (Fig. 6A).

According to Visher (1969), the cumulative distribution of grain size fractions of most sedimentary environments are built of three distinctive populations. In the case of coversands, population A is well developed (Fig. 3). It points to the predominance of transport by saltation. Four to five subpopulations (parts with different inclinations) are visible in this population $\left(A_{1}-A_{5}\right)$. Population $B$ represents transportation by suspension and is characterized by the lowest inclination, while population $\mathrm{C}$ represents the most steeply part which is responsible for transportation by traction. Points CT (refers to change from the traction 


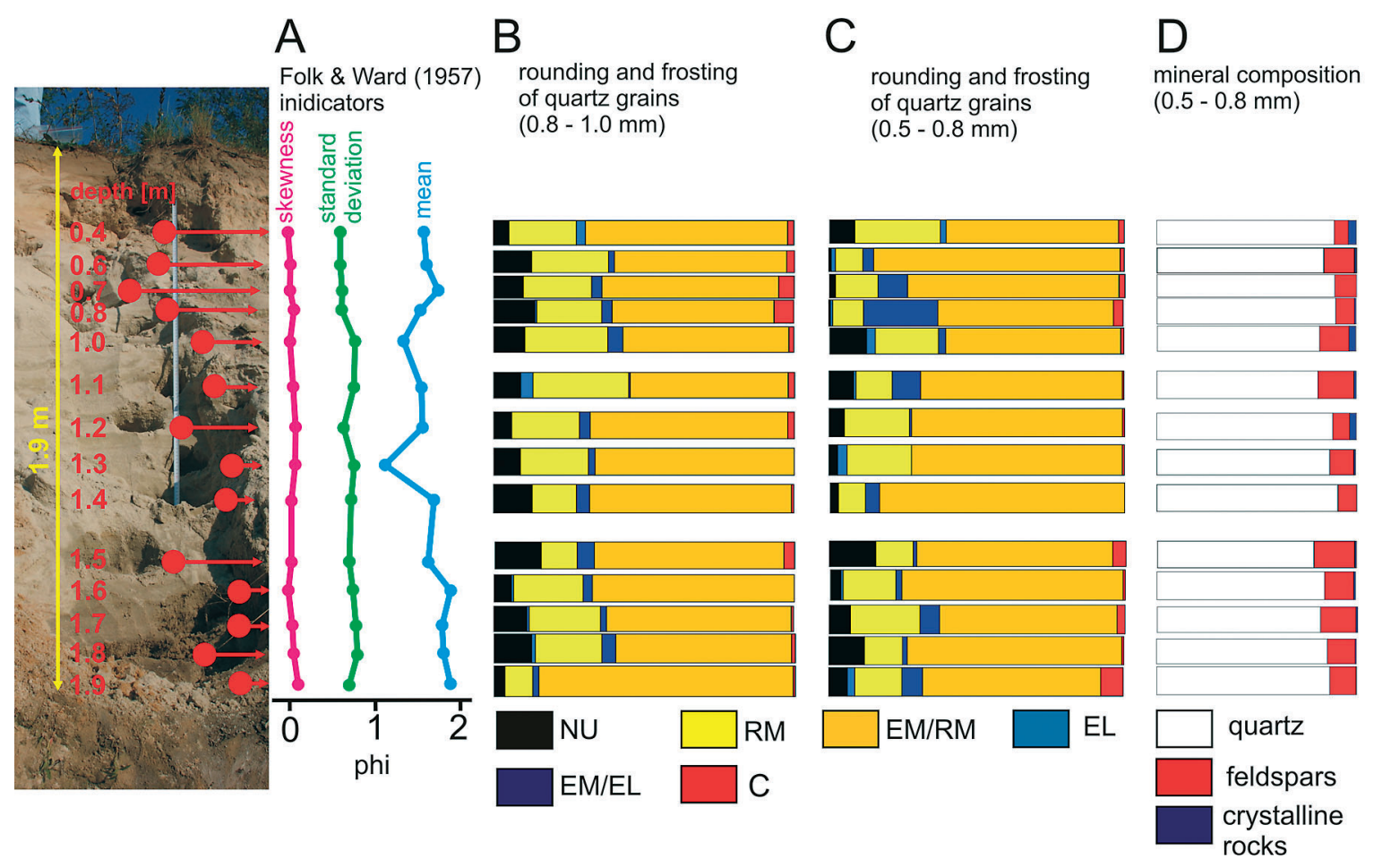

Fig. 5. Selected textural features of the coversands: A - Folk and Ward (1957) indicators; B - rounding and frosting of quartz grains $(0.8-1.0 \mathrm{~mm}$ fraction); $\mathrm{C}$ - rounding and frosting of quartz grains $(0.5-0.8 \mathrm{~mm}$ fraction); $\mathrm{D}-\mathrm{mineral}$ composition (0.5 - $0.8 \mathrm{~mm}$ fraction).

transportation to saltation) and FT (refers to change from the saltation transportation to suspension) (Fig. 4) points fall on 0.3 and 3 phi, respectively.

The frequency curves (Fig. 4) show that the investigated deposits have bimodal distribution of grain size fractions. Different modes (the highest peaks) of the curves reflect the dominating grain size. The modes which represent the coarsest sand (depths 1.0 and $1.3 \mathrm{~m}$ ) are located between $0.2-$ 0.5 and 1.6-2.0 phi, whereas the others fall between 2.0 and 3.0 phi. The higher the frequency value of the fraction, the better is the sorting of that fraction. Hence, the fractions from intervals $2-2.32$ phi (0.2$0.25 \mathrm{~mm}$ ) are characterized by the best sorting value.

\subsection{Rounding and frosting of quartz grains}

The Cailleux analysis of the $0.5-0.8 \mathrm{~mm}$ fraction (where $0.8 \mathrm{~mm}$ size is excluded, Fig. 5C; Table 1) points to enrichment in partially rounded frosted grains (EM/RM), which varies from $58.44 \%$ (depth $0.4 \mathrm{~m}$ ) to $83.33 \%$ (depths 0.6 and $1.4 \mathrm{~m}$ ). The proportion of well-rounded frosted grains (RM) changes from $9.03 \%$ (depth $1.4 \mathrm{~m}$ ) to $29.22 \%$ (depth $0.6 \mathrm{~m}$ ). The total content of matt grains (EM/RM+RM) oscillates from $70.20 \%$ (depth 0.8 $\mathrm{m}$ ) to $92.36-93.33 \%$ (depths 1.4 and 1.3). A larger content of EM/EL grains (6.66-25.17\%) is noted in the $0.5-0.8 \mathrm{~mm}$ fraction at five points of the profile: $0.7,0.9,1.1,1.7$ and $1.9 \mathrm{~m}$. The content of non-abraded grains (NU) varies within $0.66-15.72$ $\%$.

The $0.8-1.0 \mathrm{~mm}$ fraction (Fig. 5B) of the investigated deposits revealed a higher content (compared the $0.5-0.8 \mathrm{~mm}$ fraction) of wellrounded frosted grains (RM). The proportion of non-abraded grains (NU) varies within 5.22-15.5 $0 \%$ but the average content is at the level of 8-10 $\%$. Shiny, partially rounded grains (EM/EL) are in the minority $(0.65-5.63 \%)$. The $0.8-1.0 \mathrm{~mm}$ fraction contains $52.60-84.51 \%$ of partially 
rounded frosted grains (EM/RM). The highest content of EM/RM grains is noted in the basal part of the profile $(1.9 \mathrm{~m})$, near the contact with the underlying varved clays, the lowest content in the middle part of the profile $(1.1 \mathrm{~m})$.

\subsection{Mineral composition}

The quartz content varying within 78.65-90.52\% (Fig. 5D \& Table 1) is significantly high in the coversand sediments (depths 1.5 and $1.4 \mathrm{~m}$ ). The share of feldspars changes from $9.48 \%$ (depth 1.4 $\mathrm{m})$ to $20.60 \%(1.5 \mathrm{~m})$. Particles of crystalline rocks (mostly granitoids) are in the minority and their content varies within $0-4 \%$. Minerals from the mica group were not found.

\section{Chodakow profile}

The medium diameter $(\mathrm{Mz})$ varies between 1.49 and 1.7 phi but the most common interval is 1.51.57 phi (Kalinska, 2008a). Cumulative curves are characterized by well-developed parts of transportation by saltation and suspension. Two subpopulations with inclination between $50^{\circ}$ and $60^{\circ}$ are visible in the saltation part. Transportation by traction is lacking.

The sand fraction $(0.5-1.0 \mathrm{~mm})$ show a high content of partially rounded frosted (EM/RM) grains (78-86 \%). The maximal content of shiny, partially rounded quartz grains (EM/RM) reaches up to $18 \%$, with the medium value of $14 \%$. The other groups of grains (i.e. RM, EL, NU and C)

Table 1. Textural feature of coversands of the Plecewice section: Sk - skewness; $\sigma_{1}$ - standard deviation; Mz - mean; NU - non-abraded quartz grains; RM - well-rounded matt quartz grains; EM/RM - partially rounded matt quartz grains; EL - well-rounded shiny quartz grains; EM/EL - partially rounded shiny quartz grains; C - cracked quartz grains; $\mathrm{Q}$ - quartz; F - feldspars; CR - crystalline rocks.

\begin{tabular}{|c|c|c|c|c|c|c|c|c|c|}
\hline \multirow{3}{*}{$\begin{array}{l}\text { Depth } \\
(\mathrm{m})\end{array}$} & \multicolumn{9}{|c|}{ Investigated textural features } \\
\hline & \multirow[t]{2}{*}{ Sk } & \multirow{2}{*}{$\sigma_{1}$} & \multirow{2}{*}{$\begin{array}{l}\text { Mz } \\
\text { (phi) }\end{array}$} & \multicolumn{6}{|c|}{ rounding \& frosting of the $0.8-1.0 \mathrm{~mm}$ fraction quartz grains } \\
\hline & & & & $\begin{array}{l}\text { NU } \\
(\%)\end{array}$ & $\begin{array}{l}\mathrm{RM} \\
(\%)\end{array}$ & $\begin{array}{c}\text { EM/RM } \\
(\%)\end{array}$ & $\begin{array}{l}\mathrm{EL} \\
(\%)\end{array}$ & $\begin{array}{c}\mathrm{EM} / \mathrm{EL} \\
(\%)\end{array}$ & $\begin{array}{l}\mathrm{C} \\
(\%)\end{array}$ \\
\hline 0.4 & -0.18 & 0.64 & 1.69 & 5.22 & 22.38 & 67.15 & 0 & 2.98 & 2.24 \\
\hline 0.6 & 0.01 & 0.64 & 1.62 & 12.74 & 24.48 & 57.32 & 0 & 1.91 & 2.55 \\
\hline 0.7 & -0.02 & 0.67 & 1.74 & 9.80 & 22.87 & 58.82 & 0 & 3.27 & 5.23 \\
\hline 0.8 & 0.07 & 0.59 & 1.56 & 13.77 & 21.56 & 53.89 & 0.6 & 3.59 & 6.59 \\
\hline 1.0 & -0.08 & 0.84 & 1.31 & 10.43 & 27.61 & 55.21 & 0 & 4.91 & 1.84 \\
\hline 1.1 & -0.01 & 0.76 & 1.56 & 9.09 & 31.82 & 52.60 & 3.9 & 0.65 & 1.95 \\
\hline 1.2 & 0.1 & 0.68 & 1.59 & 5.84 & 26.63 & 65.69 & 0 & 3.65 & 2.19 \\
\hline 1.3 & 0.1 & 0.75 & 1.06 & 8.82 & 22.80 & 66.18 & 0 & 2.21 & 0 \\
\hline 1.4 & 0.04 & 0.67 & 1.63 & 12.82 & 14.74 & 67.31 & 0 & 4.49 & 0.64 \\
\hline 1.5 & 0.02 & 0.63 & 1.66 & 15.50 & 11.97 & 63.38 & 0 & 5.63 & 3.52 \\
\hline 1.6 & -0.02 & 0.7 & 1.9 & 5.77 & 23.10 & 67.31 & 0.6 & 3.21 & 0 \\
\hline 1.7 & 0.06 & 0.75 & 1.72 & 10.96 & 24.00 & 61.64 & 0.7 & 2.05 & 0.68 \\
\hline 1.8 & 0.06 & 0.77 & 1.52 & 12.34 & 22,10 & 58.44 & 1.3 & 4.54 & 1.30 \\
\hline 1.9 & 0.18 & 0.62 & 1.8 & 5.52 & 9.15 & 84.51 & 0 & 2.11 & 0.70 \\
\hline
\end{tabular}




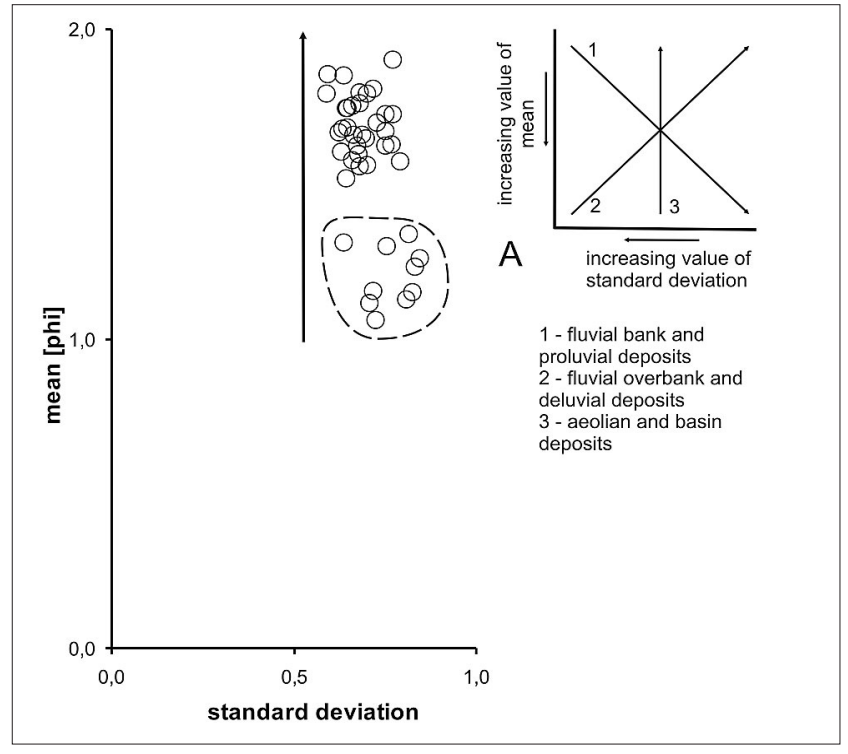

Fig. 6. Relationship between the mean diameters of grains $(\mathrm{Mz})$ and standard deviation $\left(\sigma_{1}\right)$, which represents the third type of the regression (MycielskaDowgiallo, 2007). A - types of regression (relationship) lines between the mean diameters $(\mathrm{Mz})$ and standard deviation $\left(\sigma_{1}\right)$ in the sediments of different origin (MycielskaDowgiallo, 2007).

rounding \& frosting of the $0.5-0.8 \mathrm{~mm}$ fraction quartz grains

mineral composition of the $0.5-0.8 \mathrm{~mm}$ fraction

\begin{tabular}{|l|l|l|l|l|l|l|l|l|}
\hline $\begin{array}{l}\text { NU } \\
(\%)\end{array}$ & $\begin{array}{l}\text { RM } \\
(\%)\end{array}$ & $\begin{array}{c}\text { EM/RM } \\
(\%)\end{array}$ & $\begin{array}{l}\text { EL } \\
(\%)\end{array}$ & $\begin{array}{c}\text { EM/EL } \\
(\%)\end{array}$ & $\begin{array}{l}\text { C } \\
(\%)\end{array}$ & Q & F & CR \\
\hline & & & & & & & & \\
8.44 & 29.22 & 58.44 & 0 & 1.95 & 1.95 & 89.0 & 7.0 & 4.0 \\
0.72 & 9.42 & 83.33 & 1.45 & 3.62 & 1.45 & 83.33 & 15.53 & 1.14 \\
2.04 & 14.29 & 71.43 & 0 & 10.20 & 2.04 & 88.98 & 11.02 & 0 \\
0.66 & 10.60 & 59.60 & 0.66 & 25.17 & 3.31 & 89.80 & 9.39 & 0.81 \\
12.50 & 21.43 & 59.52 & 2.98 & 2.38 & 1.19 & 81.71 & 14.79 & 3.50 \\
8.44 & 12.34 & 68.18 & 0.65 & 9.74 & 0.65 & 80.71 & 18.11 & 1.18 \\
5.26 & 21.80 & 71.43 & 0 & 0.75 & 0.75 & 88.24 & 8.45 & 3.31 \\
3.00 & 21.80 & 71.43 & 3.00 & 0 & 0.75 & 87.19 & 12.10 & 0.71 \\
2.77 & 9.03 & 83.33 & 0 & 4.86 & 0 & 90.52 & 9.48 & 0 \\
15.72 & 12.58 & 66.04 & 0 & 1.26 & 4.40 & 78.65 & 20.60 & 0.75 \\
3.57 & 17.86 & 75.0 & 0.71 & 2.14 & 0.71 & 84.36 & 14.81 & 0.82 \\
7.33 & 23.33 & 60.0 & 0 & 6.66 & 2.66 & 81.50 & 17.80 & 0.70 \\
12.10 & 12.90 & 72.58 & 0 & 1.61 & 0.80 & 85.50 & 14.00 & 0.50 \\
6.37 & 15.92 & 60.51 & 2.53 & 7.01 & 7.64 & 86.67 & 13.00 & 0.33 \\
& & & & & & & &
\end{tabular}


oscillate up to a few per cent. Significantly high quartz content in the sandy fraction $(0.5-1.0 \mathrm{~mm})$ was noted in the Chodakow profile, whereas the content of feldspars (10-11\%) is the highest at a depth of $1.2 \mathrm{~m}$. Micaceous minerals were not found.

Analysis of heavy minerals in the $0.125-0.2 \mathrm{~mm}$ fraction showed predominance of garnets (54-68 $\%)$. The most common resistant minerals are tourmalines $(2.8 \%)$, zircons $(5.2 \%)$ and staurolites (7.8 \%) (Kalinska, 2008a).

\section{Interpretation}

\subsection{Grain size}

Coversands have relatively homogeneous granulometric characteristics. They form a lag of mediumand fine-grained, moderately sorted and positively skewed sands. The coarser part of the profile at 1.3 $\mathrm{m}$ may represent a deflation pavement layer. The third system of relationship between $\mathrm{Mz}$ and $\sigma_{1}$ (Mycielska-Dowgiallo, 2007) is characteristic of the sandy deposits forming active dunes in various regions of the world (Sarre \& Chancey, 1990) and has also been recognized in Polish dunes (MycielskaDowgiallo, 1980; 2007).

The course of cumulative curves represents a rare example of deposits which come from various sedimentary environments (Mycielska-Dowgiallo, 2007). The presence of subpopulations in population A refers to a temporary changing of transportation conditions. Population B represents transportation by suspension and is characterized by the lowest inclination. It reflects poorer sorting of the smallest particles of the deposits. In turn, so steeply inclination of the population $\mathrm{C}$ is observed in deluvial deposits, whose transportation was triggered by splashing (Smolska, 2003).

\subsection{Rounding and frosting of quartz grains}

Quartz grains of aeolian origin are represented by two groups (RM and EM/RM) which have a matt (frosted) surface and a relatively high degree of rounding (Mycielska-Dowgiallo \& Woronko,
2004). In the studied samples, the great number of frosted and well- and partially-rounded types of quartz grains (RM and EM/RM) in both fraction $(0.5-0.8 \mathrm{~mm}$ and $0.8-1.0 \mathrm{~mm})$ indicates their formation under intense aeolian conditions. Simultaneously, according to the slightly varying contents of the both types of matt grains and other types of grains (e.g. EM/EL), phases with the higher and lower intensity of aeolian processes may be distinguished.

\subsection{Mineral composition}

Among light minerals, quartz and feldspars have particular value for interpretations (MycielskaDowgiallo \& Woronko, 2004). The content of quartz, a mineral highly resistant to mechanical damage, may also be the measure of resistance of deposits to abrasion. In contrast, feldspar, a mineral of low resistance to mechanical abrasion, is subject to distinct impoverishment in deposits transformed by aeolian processes (Mycielska-Dowiallo \& Woronko, 2004; Manikowska, 1982; Kobojek, 1997). Interestingly, the lower content of feldspars is compensated in almost all cases by a higher content of aeolian-type grains in the sediments. Hence, the presence of the phases reflecting different intensity of aeolian processes is also confirmed by the variation in the mineral composition of sediments.

\section{Discussion}

Two phases of the aeolian system can be distinguished in Central Poland after drying of the ice-dammed lake: constructional (Plenivistulian) and stabilizational (Late Vistulian). The maximal advance of the Vistulian ice sheet is accompanied by processes of long transportation of sand grains and simultaneous strong abrasion (Gozdzik, 2007). Hence, the high level of quartz grain roundness and frosting are observed in Central Poland (Gozdzik, 1991). Cold desert conditions and aeolian processes were still persisting at the end of the Late Plenivistulian but their intensity was lower (Gozdzik, 1991, 2007). According to model experiments (Rennsen et al., 
2007) circulation in NE and central Europe during the Late Plenivistulian was dominated by W-SW to W-NW winds, which were stronger than the SW winds in the modern climate. Climate amelioration and return of vegetation processes in the Late Vistulian radically reduced the activity of the aeolian system (Gozdzik, 2007). According to Kocurek \& Havholm (1993), younger aeolian sediments were preserved as a surface stabilization of the accumulation.

The covesands distributed on the Blonie glaciolacustrine level point to a high aeolization degree (i.e. predominance of aeolian-type grains and quartz in the sand fraction), with kind of variability in some cases. The idea of "aeolization" was introduced by Mycielska-Dowgiallo (1993). It pointed to the group of textural features which can give evidence (or confirm) not only of the types of the sedimentary environment but also of the stratigraphic position. The following aspects seem to be crucial in interpreting aeolization processes: rounding and frosting of quartz grains in the sand fraction, analysis of heavy minerals and content of the most and the least mechanically resistant particles (Mycielska-Dowgiallo, 1993, 2001). The contents of aeolian-type grains $(E M / R M+R M)$ in both analyzed fractions of the coversand are comparable with their content in dunes in southern and central Poland (Kaminska et. al., 1986; Gozdzik, 1991; Gardziel \& Morawski, 1981). At the same time, some parts of the profile at the Blonie level are characterized by a higher content of shiny, "beach-like" quartz grains, which are firmly connected with the fluvial high-energetic environment and were incorporated into coversand from the adjancent areas. Simultaneous smaller content of aeolian-type grains indicate on episode with decreasing intensity or minimization of aeolian processes in the study area. It seems possible that the lower number of frosting grains is triggered by solifluction and/or cryoturbation processes (Timireva \& Velichko, 2006). However, no cryoturbation traces were found in the investigated deposits. Decrease in frosted quartz grains in the sand fraction has also been determined in the sandy fan-like forms, mainly built of aeolian grains and located $c a .50 \mathrm{~km}$ south of the investigated area (Kalinska, 2008b, 2010; Kalinska \& Wyszomierski, 2010). This phenomenon was correlated with improvement of climatic conditions and expansion of the thin and sparse vegetation cover, which might correspond to warmer episode during the Late Glacial. Manikowska (1991) termed that episode as the Kamion Phase after a soil horizon reported below a dune in Kamion in the Wyszogrod area (60 $\mathrm{km}$ to the NW of Warsaw), corresponding to the Epe horizon in the Netherlands (Kolströp, 1980).

Relationship between RM (and EM/RM) type grains points to the duration and/or intensity of aeolian processes (Mycielska-Dowiallo \& Dzierwa, 2003; Woronko, 2001). The prevalence of EM/RM grains in sediments shows a relatively shorter duration of aeolian processes (Woronko, 2001). Hence, the aeolian processes connected with the accumulation of coversands were relatively shorter and/or not as intensive. In dunes located in Central Poland well, rounded quartz grains (RM) are more common in the $0.8-1.0 \mathrm{~mm}$ fraction of coarse sediments, whereas within finer aeolian deposits, RM-type grains most prevail in the $0.5-0.8 \mathrm{~mm}$ fraction (Mycielska-Dowgiallo \& Woronko, 2004). The different degree of rounding in the $0.5-0.8$ and 0.8 $1.0 \mathrm{~mm}$ fractions may point to various type of transportation (Mycielska-Dowgiallo \& Dzierwa, 2003). It seems that the prevalence of RM grains in the $0.8-1.0 \mathrm{~mm}$ fraction in most samples taken from coversands (Fig. 7) points on the dominance of rolling over and saltation type of transportation where the roundness of grains increased. The relationship between the wind velocities, mean size of grains $(\mathrm{Mz})$ and the phase of movement can be determined using model study (Pernarowski, 1962; Mycielska-Dowgiallo \& Dzierwa, 2003). During the accumulation of the $0.8-1.0 \mathrm{~mm}$ fraction of the coarsest parts $(1.0$ and $1.3 \mathrm{~m})$ of the investigated profile, transportation by saltation and rolling over might have prevailed at the wind velocity more than $5.25 \mathrm{~m} / \mathrm{s}$, while in the finest part of the profile (1.6$1.9 \mathrm{~m})$ the wind velocity was more than $3.8 \mathrm{~m} / \mathrm{s}$ (Table 2).

The last indicator of the aeolization value of sediments is the impoverishment in minerals of the 


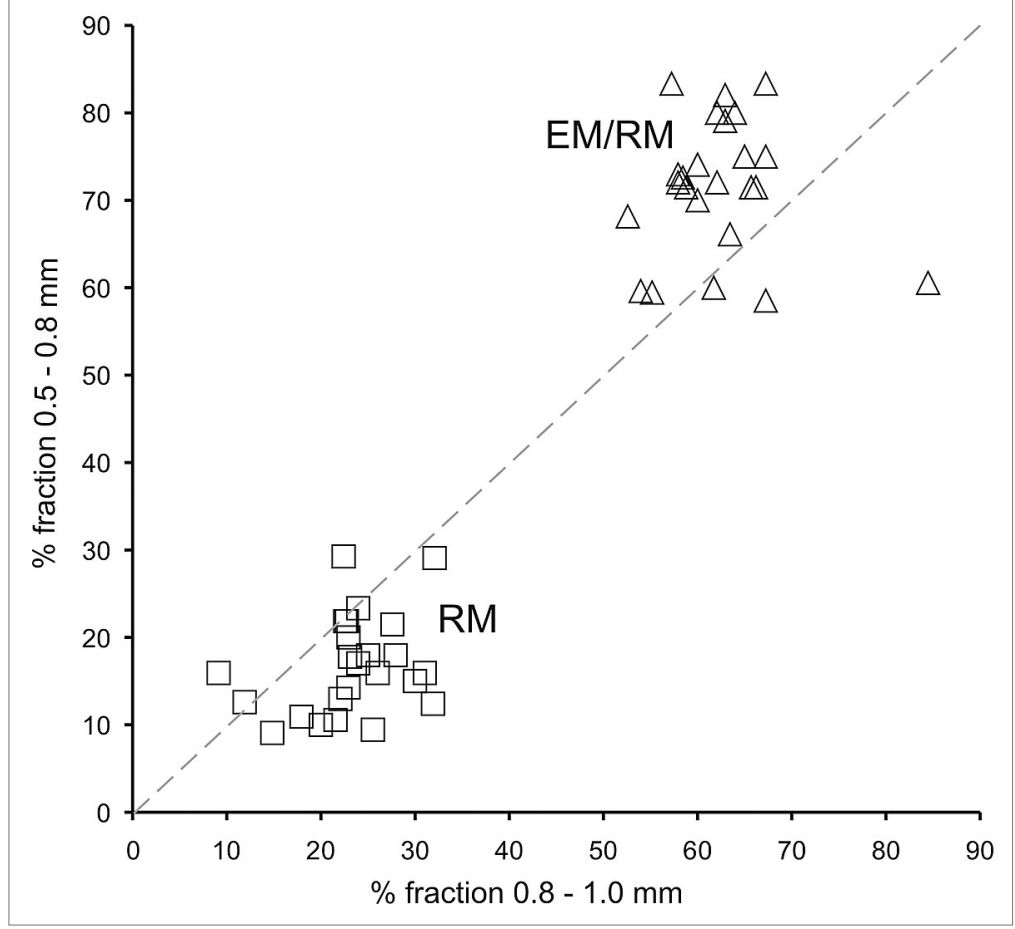

Fig. 7. Relationship between the percentages of frosted, partially rounded (EM/RM) and frosted, wellrounded (RM) quartz grains in the investigated fractions $(0.8-1.0$ and $0.5-0.8 \mathrm{~mm}$ ). Partially rounded quartz grains $(\mathrm{EM} / \mathrm{RM})$ are present in both fractions, however, the coarse fraction $(0.8-1.0 \mathrm{~mm})$ is characterized by a higher content of wellrounded (RM) grains.
Table 2. Relationship between grain size (Mz), wind velocity and the phase of movement (modified after Pernarowski, 1962 and Mycielska-Dowgiallo \& Dzierwa, 2003)

\begin{tabular}{|c|c|c|c|}
\hline \multirow{2}{*}{$\begin{array}{l}\text { Grain size } \\
(M z)\end{array}$} & \multicolumn{3}{|c|}{$\begin{array}{l}\text { Phases of movement and wind } \\
\text { velocity }(\mathrm{m} / \mathrm{s})\end{array}$} \\
\hline & $\begin{array}{l}\text { Without } \\
\text { movement }\end{array}$ & $\begin{array}{l}\text { Rolling } \\
\text { over \& } \\
\text { saltation }\end{array}$ & $\begin{array}{l}\text { Sus- } \\
\text { pension }\end{array}$ \\
\hline 1.9 phi $(\sim 0.25 \mathrm{~mm})$ & $<3.8$ & up to 5.5 & $>5.5$ \\
\hline 1.7 phi $(0.3 \mathrm{~mm})$ & $<4.5$ & up to 6 & $>6$ \\
\hline $1.32 \mathrm{phi}(\sim 0.5 \mathrm{~mm})$ & $<4.75$ & up to 6.8 & $>6.8$ \\
\hline 1.06 phi $(\sim 0.4 \mathrm{~mm})$ & $<5.25$ & up to 7.1 & $>7.1$ \\
\hline 0 phi $(1,0 \mathrm{~mm})$ & $<7.5$ & up to 10.5 & $>10.5$ \\
\hline
\end{tabular}

mica group. This group is mechanically less resistant and due to its lamellar structure more susceptible to winnowing (Mycielska-Dowgiallo, 1993). The absence of the mica group minerals was detected in the investigated profile. A total lack of mica minerals was also revealed in the coversand profile in the adjacent Chodakow area (Kalinska, 2008a, Fig. 1A) both in sand $(0.5-1.0 \mathrm{~mm})$ and heavy mineral (0.125-0.2) fractions. The average content of garnets in the Chodakow area varies within 54.7$68.3 \%$. Hence, the relationship value between amphiboles and garnets is smaller than 1.0 oscillating within $0.11-0.23$. An increase in garnet content in the repeatedly reworked aeolian deposits is usually noted due to their resistance to mechanical abrasion (Kaminska et. al., 1986; Mycielska-Dowgiallo \& Woronko, 2004).

\section{Conclusions}

The following conclusions can be drawn from the discussion of the obtained results:

- the studied deposits are dominated by fine- and medium-grained sands with layers represented by the coarse fraction;

- significant aeolization of coversand is reflected in the prevalence of frosted quartz grains (mainly EM/RM);

- the aeolian character of the depositional environment is confirmed by the presence of 
quartz grains, small content of feldspars and lack of micaceous minerals in the $0.5-1.0 \mathrm{~mm}$ fraction,

- analysis of textural features showed that coversands have of aeolian origin sediments; their textural features are comparable with dune deposits in Poland,

- coversands accumulated directly on the icevarved clays of the Warsaw ice-dammed lake after the last glacial maximum (LGM) in Poland;

- according to the presented study, the accumulation of the coversands took place in extremely dry, periglacial conditions at the wind velocities higher than $3.8 \mathrm{~m} / \mathrm{s}$ in case of the finest parts of the profile and $5.25 \mathrm{~m} / \mathrm{s}$ in the case of the coarser parts; the winds were mainly from the N-SW to N-NE.

\section{Acknowledgements}

I thank Prof. Volli Kalm (University of Tartu), Maris Nartišs (University of Latvia) and two referees for useful remarks and suggestions to improve the manuscript. This study was funded by the Postdoctoral Research Grant ERMOS (FP7 Marie Curie Cofund the "People" programme) "Age and climatic signature of coversand deposits distributed on glaciolacustrine basins along the Scandinavian Ice Sheet margin southeast of the Baltic Sea”.

\section{References}

Cailleux, A. 1942. Les actiones éoliennes périglaciaires en Europe. Mémoires de la Société Géologique de France 41, 1-176. (in French)

Cailleux, A. 1952. Morphoskopische Analyse der Geschiebe und Sandkörner und ihre bedeutung für die Paläoklimatologie. Geolgishe Rundschau 40, 11-19. (in German)

Carroll, D. 1939. Movement of sand by wind. Geological Magazine 76, 6-23.

Folk, R.L. \& Ward, W.C. 1957. Brazos River bar: a study of significance of grain size parameters. Journal of Sedimentary Research 27, 3-26.

Gardziel, Z. \& Morawski, J. 1981. Charakterystyka petrograficzna osadów wydmy parabolicznej z okolic Gizyc kolo Kocka. Folia Societatis Scientiarum Lublinensis 23, Geografia 1-2, 19-25. (in Polish)

Gozdzik, J. 1991. Sedimentological record of aeolian proces- ses in the Upper Plenivistulian and the turn of Pleni-Latevistulian in Central Poland. In: Kozarski, S. (ed.), Late Vistulian (=Weichselian) and Holocene Aeolian Phenomena in Central and Northern Europe. Zeitschrift für Geomorphologie, N.F. Supplement Band 90, 70-88.

Gozdzik, J. 2007. The Vistulian aeolian succesion in central Poland. Sedimentary Geology 193, 211-220.

Halicki, 1933. Ily wstegowe w Plecewicach nad Bzura. Zabytki Przyrody Nieozywionej 2, 86-90.

Kalinska, E. 2008a. Piaszczyste osady poziomu Chodakowskiego i doliny dolnej Bzury w swietle wybranych cech sedymentologicznych. Landform Analysis 9, 88-90. (in Polish with an English summary)

Kalinska, E. 2008b. Paleogeografia poludniowego i wschodniego obrzezenia Niziny Srodkowomazowieckiej w mlodszym plejstocenie. Ph. D. thesis, University of Warsaw. 281 p. (in Polish with an English summary)

Kalinska, E. 2010. Rozwój piaszczystych osadów form stozkopodobnych na Nizinie Mazowieckiej w mlodszym plejstocenie. Prace Wydzialu Nauk o Ziemi Uniwersytetu Slaskiego 65, 86-96. (in Polish with an English summary)

Kalinska, E. \& Wyszomierski, M. 2010. Nowe dane odnosnie genezy i wieku form stozkopodobnych poludniowej czesci Niziny Srodkowomazowieckiej. Landform Analysis 13, 27-31. (in Polish with an English summary)

Kaminska, R., Koncka-Betley, K. \& Mycielska-Dowgiallo, E. 1986. The Leszno dune in the Vistula Valley (east of Plock). Biuletyn Peryglacjalny 31, 141-162.

Karaszewski, W. 1972. Pokrywowe utwory pylowe w Polsce Srodkowej (najmlodszy less) Kwartalnik Geologiczny 16(1), 171-182. (in Polish with an English summary)

Kobojek, S. 1997. Zawartosc skaleni w utworach neoplejstocenskich okolic Czestochowy. Acta Universitatis Lodzienis, Folia Geographica Physica 1, 196-202. (in Polish)

Kocurek, G. \& Havholm, K.G. 1993. Aeolian sequence stratigraphy: a conceptual framework. In: Weimer, P. \& Posamentier., H., (eds.), Siliclastic Sequence Stratigraphy. American Association of Pertoleum Geologists Memoir 58, 393-409.

Kolströp, E. 1980. Climate and stratigraphy on nort-western Europe between $30000 \mathrm{BP}$ and $13000 \mathrm{BP}$ with special reference to the Netherlands. Mededelingen Rijks Geologische Dienst 32 (15), 181-253,

Kondracki, J. 2000. Geografia regionalna Polski. Wyd. PWN, Warszawa. 441 p. (in Polish)

Kotilainen, M. 2004. Dune stratigraphy as an indicator of holocene climatic change and human impact in northern Lapland, Finland. Annales Academiae Scientiarum Fennicae, Geologica-Geographica 166, 1-158.

Manikowska, B. 1982. Gleby kopalne w wydmach Polski Srodkowej. Rocznik Gleboznawczy 33 (3-4), 119-133. (in Polish)

Manikowska, B. 1991. Dune processes, age of dune teracce and Vistulian decline in the Vistula Valley near Wyszogród, 
Central Poland. Bulletin of Polish Academy of Sciences, Earth Sciences 39 (2), 137-148.

Marks, L. 2010. Timing of the Late Vistulian (Weichselian) glacial phases in Poland. Quaternary Science Reviews, doi:10.1016/j.quascirev.2010.08.008.

Merta, T. 1978. Extraglacial varved deposits of the Warsaw IceDammed Lake (younger Pleistocene), Mazovia Lowland, Central Poland. Acta Geologica Polonica 28, 1(2), 241272.

Mycielska-Dowgiallo, E. 1980. Cechy teksturalne i strukturalne osadów budujacych formy eoliczne w rejonie Palmyry. Prace i Studia Geograficzne 2, 189-219. (in Polish)

Mycielska-Dowgiallo, E. 1993. Estimates of Late Glacial and Holocene aeolian activity in Belgium, Poland and Sweden. Boreas 22, 165-170.

Mycielska-Dowgiallo, E. 2001. Teksturalne cechy osadów wskazujace na stopien ich eolizacji i pozycje stratygraficzna. In: Mycielska-Dowgiallo, E. (ed.), Eolizacja osadów jako wskaznik stratygraficzny czwartorzedu. Warszawa, pp. 1719. (in Polish)

Mycielska-Dowgiallo, E. 2007. Metody badan cech teksturalnych osadów klastycznych i wartosc interpretacyjna wyników. In: Mycielska-Dowgiallo, E. \& Rutkowski, J. (eds.), Badania cech teksturalnych osadów czwartorzedowych i wybrane metody oznaczania ich wieku. Wydawnictwo Szkoly Wyzszej Przymierza Rodzin, Warszawa, pp. 85180. (in Polish)

Mycielska-Dowgiallo E. \& Dzierwa, K. 2003. Rekonstrukcja dynamiki procesów eolicznych i czasu ich trwania na podstawie wybranych cech teksturalnych osadów wydmy w Cieciwie. Przeglad Geologiczny 51, 163-167. (in Polish with an English summary)

Mycielska-Dowgiallo E. \& Woronko, B. 1998. Analiza obtoczenia i zmatowienia powierzchni ziarn kwarcowych frakcji piaszczystej i jej wartosc interpretacyjna. Przeglad Geologiczny 46, 1275-1281. (in Polish with an English summary)
Mycielska-Dowgiallo, E. \& Woronko, B. 2004. The degree of aeolization of Quaternary deposits in Poland as a tool for stratigraphic interpretation. Sedimentary Geology 168, 149-163.

Pernarowski, L. 1962. O procesach wydmotwórczych. Czasopismo Geograficzne 33, 173-197. (in Polish with an English summary)

Renssen, H., Kasse, C., Vandenberghe, J. \& Lorenz, S.J. 2007. Weichselian Late Pleniglacial surface winds over nortwest and central Europe: a model-data comparision. Journal of Quaternary Science 22(3), 281-293.

Sarre, R.D. \& Chancey, C.C. 1990. Size segregation during aeolian saltation on sand dunes. Sedimentology 37, 357365.

Smolska, E. 2003. Cechy deluwiów na przykladzie osadów stokowych pagórka w okolicy Lopuchowa na Pojezierzu Suwalskim. In. Smolska, E. \& Szwarczewski, P. (eds.), Cechy teksturalne osadów stokowych i fluwialnych. Prace i Studia Geograficzne 22, Warszawa, pp. 45-57. (in Polish)

Szumanski, A. \& Kwapisz, B. 2006. Szczególowa mapa geologiczna Polski 1:50 000, arkusz Blonie. Panstwowy Instytut Geologiczny, Warszawa. (in Polish)

Timireva, S.N. \& Velichko, A.A. 2006. Depositional environments of the Pleistocene loess-soil series inferred from sand grain morphoscopy - a case study of the East European Plain. Quaternary International 152-152, 136-145.

Visher, G.T. 1969. Grain size distribution and depositional processes. Journal of Sedimentary Petrology 39, 10741106.

Woronko, B. 2001. Znaczenie analizy obtoczenia i zmatowienia powierzchni ziarn kwarcu frakcji piaszczystej w interpretacji genetycznej osadów czwartorzedowych. In: Mycielska-Dowgiallo, E. (ed.), Eolizacja osadów jako wskaznik stratygraficzny czwartorzedu. Warszawa, pp. 33-38. (in Polish)

Zeeberg, J. 1998. The European sand belt in eastern Europe and comparison of Late Glacial dune orientation with GCM simulation results. Boreas 27(2), 127-139. 